Sigurd Høye (f. 1972) er assisterende medisinsk redaktør i Tidsskriftet og forsker ved Antibiotikasenteret for primærmedisin, Avdeling for allmennmedisin, Universitetet i Oslo. Hans doktoravhandling fra 2013 omhandlet vent-og-se-resept.

\title{
Heller sprettert enn kanon
}

I en amerikansk studie reduserte allmennleger forskrivningsraten av antibiotika ved akutt bronkitt fra $74 \%$ til $61 \%$ (1). Dette var på mange måter et imponerende resultat. Men en forskrivningsrate på $61 \%$ for en tilstand der legemidlet knapt har effekt, ville i alle andre sammenhenger vært betegnet som en fiasko (2). Velkommen til antibiotikaens forunderlige verden.

Antibiotika har et ufortjent godt rykte ved behandling av luftveisinfeksjoner i allmennpraksis. Bruken er høy, men nytten er lav eller fraværende. Hva skyldes denne overdrevne og overflødige bruken? To hovedårsaker er identifisert: prognostisk usikkerhet og opplevd pasientforventning om antibiotika (3).

Den prognostiske usikkerheten henger sammen med allmennmedisinens arbeidsmetode. I allmennpraksis er diagnostikk oftest basert på sykehistorie, symptomer, funn, undersøkelse og enkle hurtigtester. Kostbare bildeundersøkelser og mikrobiologiske undersøkelser med lang svartid passer dårlig med allmennlegens portvaktfunksjon og behovet for rask håndtering av pasientenes plager. Allmennlegen må iverksette tiltak uten å ha et sikkert svar på om plagene skyldes bronkitt eller pneumoni, om infeksjonen er forårsaket av virus eller bakterier, eller om pasienten vil ha utbytte av antibiotika eller ei. Usikkerheten vil ofte komme antibiotikaprodusenten - og ikke nødvendigvis pasienten - til gode. På samme måte øker risikoen for å få antibiotika når legen opplever at pasienten forventer slik behandling (4).

Allmennmedisinske forskere har vært opptatt av å finne tiltak som kan redusere både den prognostiske usikkerheten og opplevelsen av at pasienten forventer antibiotika. Introduksjon av hurtigtester som CRP-test og Strep A-test har gitt en betydelig reduksjon av antibiotikabruken (5). Bruken av slike tester er stor i Norge og de andre nordiske landene, og dette kan være en av årsakene til den relativt lave forskrivningsraten vi har hos oss. Ekspektans som hjelpemiddel til å redusere den prognostiske usikkerheten, for eksempel ved bruk av vent-og-se-resept, kan også bidra (6). Kurs for leger i å få frem pasientens egentlige forventninger har også vist god effekt - pasienter foretrekker vanligvis grundig undersøkelse og god informasjon fremfor en resept på antibiotika (5).

En annen tilnærming er å undersøke om andre behandlingsalternativer enn systemisk antibiotika kan ha like god, eller bedre, effekt. I en ny studie ble antibiotika sammenliknet med ibuprofen ved akutt bronkitt (7). Tanken er at den langvarige hosten som ofte følger med en bronkitt, og som gjerne bringer pasienten til lege, mer skyldes postinfeksiøs inflammasjon enn infeksjon. Pasientene ble like fort friske enten de fikk antibiotika, ibuprofen - eller placebo. Bivirkninger forekom hyppigst i antibiotikagruppen. Mer lovende er det at ibuprofen har vist god effekt ved ukomplisert cystitt i en pilotstudie (8). En påbegynt internasjonal studie med utgangspunkt i norsk allmennpraksis vil kunne gi svar på om ibuprofen er likeverdig med mecillinam ved denne tilstanden (9). Og i dette nummeret av Tidsskriftet presenterer Nielsen og medarbeidere en studie der de har funnet overraskende god effekt av kloramfenikol øyedråper $i$ behandling av sinusittliknende plager (10). Selv om kloramfenikol også er et antibiotikum, er den lokale applikasjonen langt å foretrekke fremfor systemisk antibiotika på grunn av lavere risiko for bivirkninger og resistensutvikling. Om resultatene fra denne studien kan reproduseres i større studier med mer robust design, er usikkert - men resultatene er i hvert fall interessante nok til at noen burde prøve.

Det beste ville være å slutte helt med å forskrive antibiotika ved milde luftveisinfeksjoner. Men det er et stykke frem. Utvikling av gode og mindre skadelige alternativer til systemisk antibiotika er derfor velkomment. Hvis man absolutt vil skyte spurv, er sprettert bedre enn kanoner. Kanonene bør spares til større farer.

\section{Litteratur}

1. Gonzales R, Anderer T, McCulloch CE et al. A cluster randomized trial of decision support strategies for reducing antibiotic use in acute bronchitis. JAMA Intern Med 2013; 173: 267-73.

2. Linder JA. Antibiotic Prescribing for acute respiratory infections-success that's way off the mark: comment on «A cluster randomized trial of decision support strategies for reducing antibiotic use in acute bronchitis». JAMA Intern Med 2013: 173: 273-5.

3. Cals JW. Respiratory tract infections in general practice. Doktorgradsavhandling. Maastricht: School for Public Health and Primary Care, Maastricht University, 2009 .

4. Little P. Dorward M, Warner G et al. Importance of patient pressure and perceived pressure and perceived medical need for investigations, referral, and prescribing in primary care: nested observational study. BMJ 2004; 328: 444

5. Little P, Stuart B. Francis N et al. Effects of internet-based training on antibiotic prescribing rates for acute respiratory-tract infections: a multinational, cluster, randomised, factorial, controlled trial. Lancet 2013; 382: 1175-82.

6. Spurling GK, Del Mar CB, Dooley L et al. Delayed antibiotics for respiratory infections. Cochrane Database Syst Rev 2013; nr. 4: CD004417.

7. Llor C, Moragas A, Bayona C et al. Efficacy of anti-inflammatory or antibiotic treatment in patients with non-complicated acute bronchitis and discoloured sputum: randomised placebo controlled trial. BMJ 2013; 347: f5762

8. Bleidorn J, Gágyor I, Kochen MM et al. Symptomatic treatment (ibuprofen) or antibiotics (ciprofloxacin) for uncomplicated urinary tract infection?-results of a randomized controlled pilot trial. BMC Med 2010; 8: 30.

9. ClinicalTrials.gov. Ibuprofen versus mecillinam for uncomplicated cystitis (IMUTI). clinicaltrials.gov/show/NCT01849926 (21.10.2013).

10. Nielsen IR, Seim A, Bentzen N. Kloramfenikol øyedråper i behandling av maxillarsinusittliknende plager. Tidsskr Nor Legeforen 2013; 133: 2146-8. 